\title{
Genetic Transfer in a Nitrogen-fixing Filamentous Cyanobacterium
}

\author{
By KESHAV TREHAN†* AND UMAKANT SINHA \\ Laboratory of Microbial and Molecular Genetics, Department of Botany, University of \\ Delhi, Delhi 110007, India
}

(Received 9 April 1980; revised 27 October 1980)

Genetic transfer has been studied between wild-type Nostoc muscorum and a multiply marked mutant strain. Experiments conducted with heat-killed donor and live recipient cells indicated that the transfer occurred in both directions and may have been the result of transformation rather than conjugation. This conclusion was supported by the sensitivity of the process to DNAase. There was some indication of linkage between het and $e t h$.

\section{INTRODUCTION}

Genetic recombination in mixed cultures of cyanobacterial mutants has been described in the unicellular Anacystis nidulans (Kumar, 1962; Bazin, 1968) and the filamentous Cylindrospermum majus (Singh \& Sinha, 1965), Anabaena doliolum (Singh, 1967) and Nostoc muscorum (Stewart \& Singh, 1975; Padhy \& Singh, 1978). Genetic transformation in cyanobacteria mediated by purified DNA, has been described only for unicellular forms (Shestakov \& Khyen, 1970; Herdman, 1973; Orkwiszewski \& Kaney, 1974; Devilly \& Houghton, 1977). Transformation mediated by nucleic acids excreted by the cells of Anacystis nidulans into the culture medium has also been reported (Herdman, 1973).

Nostoc muscorum is a heterocystous filamentous $\mathrm{N}_{2}$-fixing organism which can be conveniently manipulated. Single cells can be easily obtained and the organism also forms discrete colonies which are convenient for genetic analysis. In the present investigation, auxotrophic and drug-resistant mutants have been utilized to study genetic recombination in $N$. muscorum further. A system of transformation, operating in mixed cultures of parental cells, is described.

\section{METHODS}

Organism and growth conditions. Wild-type Nostoc muscorum was kindly supplied by the late Professor R. N. Singh, Banaras Hindu University, Varanasi, India. The minimal medium (MM) used throughout the study was medium BG-11 (Allen, 1968) with $\mathrm{NaNO}_{3}$ omitted. Axenic cultures were maintained in $\mathrm{MM}$ in a culture room at $27^{\circ} \mathrm{C}$, with cool white fluorescent tubes producing about $2500 \mathrm{~lx}$ at the culture surface. The culture flasks $(125 \mathrm{ml})$ were shaken at hourly intervals in order to prevent clumping and wall growth. For colony growth $0.1 \mathrm{ml}$ of a diluted culture ( 200 cells $\mathrm{ml}^{-1}$ ) was spread on MM agar plates. Following incubation, single colonies were transferred with sterile glass capillaries to culture tubes containing $10 \mathrm{ml}$ of sterile liquid $\mathrm{MM}$. The resulting clonal populations were used throughout. Cell counts were made in a Neubauer counting chamber.

Mutagenesis. $N$-Methyl- $N^{\prime}$-nitro- $N$-nitrosoguanidine (NTG) was used as mutagen. Exponentially growing cells were harvested by membrane filtration (pore size $0.8 \mu \mathrm{m}$ ), washed with $0.05 \mathrm{M}$-Tris/maleic acid buffer, $\mathrm{pH} 8.0$ (Adelberg et al., 1965) and resuspended in $15 \mathrm{ml}$ of Tris/maleic acid buffer, $\mathrm{pH} \mathrm{5.0.} \mathrm{Freshly} \mathrm{prepared} \mathrm{saturated}$ NTG solution (in water) was added to $10 \mathrm{ml}$ of cell suspension to give a final concentration of about $100 \mu \mathrm{g} \mathrm{ml}$. The suspension was stirred on a magnetic stirrer for $20 \mathrm{~min}$, filtered on membrane filters and washed five times with MM ( $\mathrm{pH} \mathrm{8)}$. The cells were then suspended in $\mathrm{MM}$, and $0.1 \mathrm{ml}$ portions were spread on MM agar plates

$\dagger$ Present address: Laboratory of Microbial Genetics and Biochemistry, Department of Botany, Kurukshetra University, Kurukshetra 132119 , India. 
supplemented with ethionine $\left(0.04 \mathrm{mg} \mathrm{m}^{-1}\right)$ and incubated for 7 to $10 \mathrm{~d}$. The surviving colonies were scored as ethionine-resistant $\left(\mathrm{Eth}^{\mathrm{R}}\right)$ mutants and were isolated and re-tested for their resistance. The Eth ${ }^{\mathbf{R}}$ mutant employed in further studies was non-heterocystous ( Het $\left.^{-}\right)$.

A valine auxotroph $\left(\mathrm{Val}^{-}\right)$was derived from this $\mathrm{Eth}^{\mathrm{R}} \mathrm{Het}^{-}$mutant by further mutagenesis with NTG, and was isolated by the penicillin enrichment technique developed by Davis (1948) and adapted by Ingram et al. (1972) and Herdman \& Carr (1972) for use with cyanobacteria. Following mutagenesis, cells were inoculated into a flask containing $\mathrm{MM}$ plus penicillin $\left(150 \mu \mathrm{g} \mathrm{ml}^{-1}\right)$. Seven transfers were made at $48 \mathrm{~h}$ intervals to enrich the mutant population. The cells were then centrifuged, suspended in fresh $\mathrm{MM}$ and inoculated into a series of test tubes containing $\mathrm{MM}$ plus valine. These tubes were incubated in the light at $27^{\circ} \mathrm{C}$ and growth was observed. Alternatively, the cells were plated on MM plus valine, the resulting colonies were replica plated on to MM, and $\mathrm{Val}^{-}$mutants were identified by their growth response. The $\mathrm{Val}^{-}$mutant studied required $20 \mu \mathrm{g}$ valine $\mathrm{ml}^{-1}$ for optimum growth.

Recombination experiments. All recombination experiments were started with suspensions of single cells, obtained by shaking with sterilized glass beads (which gave $98 \%$ survival). The cells were washed two or three times with sterile distilled water and MM by centrifuging at $3000 \mathrm{rev}$. $\mathrm{min}^{-1}$. Suspensions of each strain in MM (3 $\times 10^{6}$ cells $\mathrm{ml}^{-1}$ ) were mixed together and agitated continuously on a magnetic stirrer, or slowly by hand, at $27^{\circ} \mathrm{C}$. Recombination procedures were as reported by Singh et al. (1965). Recombinants were selected on agar plates, counterselecting the parental types, and were scored repeatedly for stability of characters. Het ${ }^{-}$ recombinants were identified microscopically. Frequencies of recombinants were calculated in relation to the total cell population plated.

DNAase treatment. DNAase $\left(20 \mu \mathrm{g} \mathrm{m}^{-1}\right)$ and $\mathrm{MgCl}_{2}(2 \mathrm{mM})$ were added to a mixed culture of cells and the mixture was incubated for 4 or $8 \mathrm{~h}$ at $27 \pm 2{ }^{\circ} \mathrm{C}, \mathrm{pH} 7 \cdot 5$.

Chemicals. NTG was obtained from Fluka, Buchs, Switzerland, and DNAase from Sigma. Analytical grade chemicals, obtained from BDH, were used throughout.

\section{RESULTS AND DISCUSSION}

Recombinant formation with equal numbers of wild-type and mutant cells. Equal numbers of cells $\left(3 \times 10^{6} \mathrm{ml}^{-1}\right)$ of the wild-type and the $\mathrm{Het}^{-} \mathrm{Eth}^{\mathrm{R}} \mathrm{Val}^{-}$mutant were mixed together. At intervals, cells were plated on MM plus ethionine, thereby selecting against both of the parental strains and selecting for $\mathrm{Val}^{+} \mathrm{Eth}^{\mathbf{R}}$ recombinants. The maximum frequency of recombinant formation occurred when the cells were incubated together for $4 \mathrm{~h}$, the frequency decreasing (perhaps due to extracellular digestion of genetic material) with further increase in the incubation time (Table 1). Although all the recombinants were able to grow in MM, 30 to $37.5 \%$ of them were $\mathrm{Het}^{-}$. It is not clear how the latter were able to grow aerobically at the expense of $\mathrm{N}_{2}$. The appearance of $\mathrm{Het}^{+} \mathrm{Eth}^{\mathrm{R}}$ recombinants indicated that ethionine resistance and the ability to form heterocysts are controlled by two different genes and that mutation in both had been induced simultaneously.

Effect of varying proportions of wild-type and mutant cells on the frequency of gene transfer. When the cell density of the wild-type was varied (from $1 \times 10^{2}$ to $6 \times 10^{6}$ cells $\left.\mathrm{ml}^{-1}\right)$ and that of the mutant $\left(\mathrm{Het}^{-} \mathrm{Eth}^{\mathbf{R}} \mathrm{Val}^{-}\right)$was kept constant $\left(3 \times 10^{6}\right.$ cells $\left.\mathrm{ml}^{-1}\right)$, the frequency of recombinants increased with increasing cell density of the wild-type (Table 2). However, the frequency of $\mathrm{Het}^{-} \mathrm{Eth}^{\mathrm{R}} \mathrm{Val}^{+}$colonies among the recombinants was always more than $50 \%$, which indicated the possible linkage of het and eth.

When the concentration of the mutant cells was varied and that of the wild-type kept constant, the frequency of recombinants did not show any appreciable change except at very low concentrations of the mutant strain (Table 3). The frequency of $\mathrm{Het}^{-} \mathrm{Eth}^{\mathrm{R}} \mathrm{Val}^{+}$colonies was always more than $58 \%$, again indicating possible linkage between het and eth.

Effect of heat killing of cells on gene transfer. To study the nature of the gene transfer process further, each of the strains was killed by heat treatment $\left(100^{\circ} \mathrm{C}\right.$ for $\left.10 \mathrm{~min}\right)$ and then mixed with the appropriate live strain in equal proportions $\left(3 \times 10^{6}\right.$ cells $\left.\mathrm{ml}^{-1}\right)$. The viability of heat-killed cells was less than $1 \times 10^{-6}$. When the wild-type cells were killed the maximum frequency of $\mathrm{Eth}^{\mathrm{R}} \mathrm{Val}^{+}$recombinants was $0.07 \%$ after incubation with living $\mathrm{Het}^{-} \mathrm{Eth}^{\mathrm{R}} \mathrm{Val}^{-}$ cells for 2 to $8 \mathrm{~h}$. This value is quite close to those obtained after mixing live strains (Table 1) 
Table 1. Effect of duration of contact on recombinant formation in $N$. muscorum

Equal volumes of suspensions $\left(3 \times 10^{6}\right.$ cells $\left.\mathrm{ml}^{-1}\right)$ of the wild-type and the $\mathrm{Het}^{-} \mathrm{Eth}^{\mathrm{R}} \mathrm{Val}^{-}$mutant were mixed together and incubated for the periods shown before plating on $\mathbf{M M}$ plus ethionine. The spontaneous frequency of mutation to ethionine resistance was $2 \times 10^{-7}$; in each experiment $2.4 \times 10^{6}$ cells were plated.

Duration of contact
before plating $(\mathrm{h})$

4

8

14

24
No. of recombinants $\left(\mathrm{Val}^{+} \mathrm{Eth}^{\mathrm{R}}\right)$

2523

2164

1452

487
Frequency of recombinants (\%)
0.10
0.09
0.06
0.02

Table 2. Effect of cell density of the wild-type on recombinant formation in N. muscorum

Recombination experiments were performed as described in Methods, with the cell density of the Het $^{-}$Eth $^{\mathrm{R}} \mathrm{Val}^{-}$mutant kept constant at $3 \times 10^{6} \mathrm{cells} \mathrm{ml}^{-1}$ and that of the wild-type varied as shown.

No. of wild-typ
cells mi $^{-1}$
$6 \times 10^{6}$
$5 \times 10^{6}$
$4 \times 10^{6}$
$3 \times 10^{6}$
$2 \times 10^{6}$
$1 \times 10^{6}$
$1 \times 10^{5}$
$1 \times 10^{4}$
$1 \times 10^{3}$
$1 \times 10^{2}$

Total no. of cells
plated

$1.1 \times 10^{6}$

$1.0 \times 10^{6}$

$1.75 \times 10^{6}$

$1.5 \times 10^{6}$

$1.25 \times 10^{6}$

$1.0 \times 10^{6}$

$7.5 \times 10^{5}$

$1.5 \times 10^{5}$

$1.5 \times 10^{5}$

$1.5 \times 10^{5}$
Frequency of recombinants (\%)
$0 \cdot 12$
$0 \cdot 10$
$0 \cdot 10$
0.10
0.09
0.08
0.06
0.02
0.006
0.001

Table 3. Effect of cell density of the mutant on recombinant formation in N. muscorum

Recombination experiments were performed as described in Methods, with the cell density of the wild-type kept constant at $3 \times 10^{6}$ cells $\mathrm{ml}^{-1}$ and that of the Het $\mathrm{Eth}^{\mathrm{R}} \mathrm{Val} \mathrm{I}^{-}$mutant varied as shown.

$\begin{array}{ccc}\begin{array}{c}\text { No. of mutant } \\ \text { cells ml }\end{array} & \begin{array}{c}\text { Total no. of cells } \\ \text { plated }\end{array} & \begin{array}{c}\text { Frequency of } \\ \text { recombinants }(\%)\end{array} \\ 6 \times 10^{6} & 1.1 \times 10^{6} & 0.10 \\ 5 \times 10^{6} & 1.0 \times 10^{6} & 0.10 \\ 4 \times 10^{6} & 1.75 \times 10^{6} & 0.10 \\ 3 \times 10^{6} & 1.5 \times 10^{6} & 0.10 \\ 2 \times 10^{6} & 1.25 \times 10^{6} & 0.10 \\ 1 \times 10^{6} & 1.0 \times 10^{6} & 0.10 \\ 1 \times 10^{5} & 7.5 \times 10^{5} & 0.10 \\ 1 \times 10^{4} & 7.5 \times 10^{5} & 0.05 \\ 1 \times 10^{3} & 7.5 \times 10^{5} & 0.02 \\ 1 \times 10^{2} & 7.5 \times 10^{5} & 0.004\end{array}$

and indicated that genes are transferred from the wild-type to the mutant. When the mutant strain was heat-killed, the maximum frequency of recombinants was $0.018 \%$. Thus, gene transfer from the mutant to the wild-type was also taking place. These results demonstrated that both strains were able to donate and receive genetic material, and that transfer did not require a live donor strain.

Effect of DNAase on gene transfer. DNAase treatment reduced recombinant formation by at least $97 \%$, the frequency of recombinants decreasing to $0.003 \%$ and $0.002 \%$ following incubation with DNAase for $4 \mathrm{~h}$ and $8 \mathrm{~h}$, respectively. This suggests that gene transfer was the result of transformation. The residual transfer observed following DNAase treatment may 
result from incomplete digestion of the DNA, or from an alternative gene transfer system which operates at low frequency.

We are grateful to Professors B. M. Johri, H. Y. Mohan Ram and R. N. Kapil for facilities and encouragement. This work was supported by financial assistance from the Council of Scientific and Industrial Research, New Delhi, India.

\section{REFERENCES}

Adelberg, E. A., Mandel, M. \& Ching Chen, G. C. (1965). Optimal conditions for mutagenesis by $N$-methyl- $N^{\prime}$-nitro- $N$-nitrosoguanidine in Escherichia coli K-12. Biochemical and Biophysical Research Communications 18, 788-795.

ALLEN, M. M. (1968). Simple conditions for the growth of unicellular blue-green algae on plates. Journal of Phycology 4, 1-3.

BAzIN, M. J. (1968). Sexuality in a blue-green alga: genetic recombination in Anacystis nidulans. Nature, London 218, 282-283.

DAvis, B. D. (1948). Isolation of biochemically deficient mutants of bacteria by penicillin. Journal of the American Chemical Society 70, 4267.

Devilly, C. I. \& Houghton, J. A. (1977). A study of genetic transformation in Gloeocapsa alpicola. Journal of General Microbiology 98, 277-280.

Herdman, M. (1973). Mutations arising during transformation in the blue-green alga Anacystis nidulans. Molecular and General Genetics 120, 369-378.

Herdman, M. \& CarR, N. G. (1972). The isolation and characterization of mutant strains of the blue-green alga Anacystis nidulans. Journal of General Microbiology 70, 213-220.

Ingram, L. O., Pierson, D., Kane, J. F., Van BAAlen, C. \& Jensen, R. A. (1972). Documentation of auxotrophic mutation in blue-green bacteria: characterization of a tryptophan auxotroph in Agmenellum quadruplicatum. Journal of Bacterio$\log y 111,112-118$.
KUMAR, H. D. (1962). Apparent genetic recombination in a blue-green alga. Nature, London 196, 1121.

ORKWISZEWSKI, K. G. \& KANEY, A. R. (1974). Genetic transformation of the blue-green bacterium Anacystis nidulans. Archives of Microbiology 98, 31-37.

PADHY, R. N. \& Singh, P. K. (1978). Genetical studies on the heterocyst and nitrogen fixation in blue-green algae. Molecular and General Genetics 162, 203211.

Shestakov, S. V. \& KhYEN, N. T. (1970). Evidence for genetic transformation in the blue-green alga Anacystis nidulans. Molecular and General Genetics 107, 372-375.

SINGH, H. N. (1967). Genetic control of sporulation in the blue-green alga Anabaena doliolum Bhardwaja. Planta 75, 33-38.

Singh, R. N. \& Sinha, R. (1965). Genetic recombination in a blue-green alga Cylindrospermum majus. Nature, London 207, 782-783.

Singh, R. N., Singh, H. N. \& SinHA, R. (1965). Mutation and recombination in blue-green algae. Indian Journal of Genetics 26A, 405-430.

StewarT, W. D. P. \& SingH, H. N. (1975). Transfer of nitrogen-fixing (nif) genes in the blue-green alga Nostoc muscorum. Biochemical and Biophysical Research Communications 62, 62-69. 